\title{
HUBUNGAN PEMBERIAN ASI EKSKLUSIF TERHADAP PERKEMBANGAN BAYI USIA 0 - 6 BULAN DI INDONESIA
}

\author{
Andi Siti Matahari Adela ${ }^{1}$, Darma Ariany ${ }^{1 *}$, Salmah Suciaty ${ }^{1}$, \\ ${ }^{1}$ Program Studi Pendidikan Dokter, Fakultas Kedokteran Universitas Alkhairat, Jl. Diponegoro No. 39 \\ Palu 94221, Sulawesi Tengah, Indonesia \\ *Corresponding author: Telp: +6285217533043 email: darma_ariany@yahoo.co.id
}

\begin{abstract}
ABSTRAK
WHO menyatakan sekitar $15 \%$ dari total kasus kematian anak di bawah usia lima tahun di negara berkembang disebabkan oleh pemberian ASI secara tidak eksklusif. Berbagai masalah gizi kurang maupun gizi lebih juga timbul akibat dari pemberian makanan sebelum bayi berusia 6 bulan. Anak - anak yang tidak cukup ASI akan terganggu proses tumbuh kembangnya. Penelitian bertujuan untuk mengetahui ada tidaknya Hubungan Pemberian ASI Eksklusif Terhadap Perkembangan Bayi Usia 0-6 Bulan di Indonesia. Design penelitian yang digunakan adalah metode studi literature yang dimana mengumpulkan data pustaka, hasil penelitian penelitian yang telah dilakukan dan berhubungan dengan topic penelitian ini serta membaca dan memahami dari isi tiap penelitian 10 jurnal dengan besar sampel sebanyak 737 bayi . Penelitian ini Dilakukan analisis dengan uji Chi Square menggunakan SPSS 24.0. Hasil menunjukkan bahwa (1) Hasiil penelitian yang terdapat kategori meragukan, didapatkan perkembangan yang sesuai lebih banyak ditemukan pada bayi yang diberikan ASI eksklusif dari pada yang tidak diberikan ASI Eksklusif (80 vs 60). Perkembangan yang menyimpang ditemukan lebih banyak pada bayi yang tidak diberikan ASI Eksklusif daripada yang diberikan ASI Eksklusif (18 vs 1) . Didapatkan nilai $\mathrm{p}<0,05$ yaitu 0,00 sehingga ASI eksklusif berhubungan dengan perkembangan (2) Dari kelima penelitian yang tidak terdapat kategori meragukan , perkembangan yang sesuai lebih banyak ditemukan pada bayi yang diberikan ASI eksklusif dari pada yang tidak diberikan ASI Eksklusif ( 172 vs149 ). Perkembangan yang menyimpang ditemukan lebih banyak pada bayi yang tidak diberikan ASI Eksklusif daripada yang diberikan ASI Eksklusif (11 vs72) . Peneltian ini menunjukkan nilai $\mathrm{p}<0,05$ yaitu 0,001 sehingga dapat dikatakan saling berhubungan antara pemberian ASI eksklusif dan perkembangan bayi. Disimpulkan bahwa Pemberian ASI eksklusif dengan perkembangan bayi di Indonesia terdapat hubungan yang signifikan dan bermakna.
\end{abstract}

Kata Kunci: ASI, Eksklusif, Bayi

\section{ABSTRACT}

WHO reports that about $15 \%$ of the total deaths of children under the age of five in developing countries are caused by non-exclusive breastfeeding. Various problems of undernutrition and overnutrition also arise as a result of giving food before the baby is 6 months old. Children children who do not get enough breast milk will be disturbed in the process of growth and development. This study aims to determine whether there is a relationship between exclusive breastfeeding and the development of infants aged 0-6 months in Indonesia. The research design used is a literature study method which collects library data, the results of studies that have been carried out and related to the topic of this research as well as reading and understanding the contents of each study of 10 journals with a sample size of 737 infants. This research was analyzed by Chi Square test using SPSS 24.0. The results showed that (1) The results of the study were in a dubious category, found that appropriate development was more found in infants who were exclusively breastfed than those who were not given exclusive breastfeeding (80 vs 60). Deviant development was found more in infants who were not exclusively breastfed than those who were exclusively breastfed (18 vs 1). The $p$ value $<0.05$ is 0.00 so that exclusive 
breastfeeding is related to development (2) Of the five studies that did not have any doubtful categories, the appropriate development was found in infants who were exclusively breastfed than those who were not given exclusive breastfeeding (172 vs149). Developmental aberrations were found more in infants who were not exclusively breastfed than those who were exclusively breastfed (11 vs72). This research shows a p value $<0.05$, which is 0.001 so that it can be said that there is a relationship between exclusive breastfeeding and infant development. It was concluded that exclusive breastfeeding and infant development in Indonesia had a significant and significant relationship.

Keywords: Breastfeeding, Exclusive, Baby

\section{PENDAHULUAN}

ASI eksklusif didefinisikan sebagai makanan selama 6 bulan kehidupan pertama tanpa ada tambahan makanan atau minuman lain, bahkan air, tetapi memungkinkan bayi untuk menerima oralit, tetes dan sirup (vitamin, mineral dan obat-obatan ). ${ }^{1}$

UNICEF dan WHO merekomendasikan pemberian ASI eksklusif sampai bayi berusia 6 bulan. Adabnya faktor protektif dan nutrien yang sesuai dalam ASI menjamin status gizi baik. Beberapa penelitian mengkatakan bahwa ASI melindungi bayi dan anak dari penyakit infeksi, misalnya diare dan infeksi saluran pernafasan akut bagian bawah. Kolostrum mengandung zat kekebalan 10 -17 kali lebih banyak dari susu matang.

Manfaat pemberian ASI eksklusif sesuai dengan salah satu tujuan dari Millenium Development Goals (MDGs) yaitu mengurangi tingkat kematian anak dan meningkatkan kesehatan Ibu. WHO menyatakan sekitar $15 \%$ dari total kasus kematian anak di bawah usia lima tahun di negara berkembang disebabkan oleh pemberian ASI secara tidak eksklusif. Berbagai masalah gizi kurang maupun gizi lebih juga timbul akibat dari pemberian makanan sebelum bayi berusia 6 bulan. Anak - anak yang tidak cukup ASI akan terganggu proses tumbuh kembangnya. ${ }^{2}$

Perkembangan adalah bertambahnya kemampuan ( skill ) dalam struktur dan fungsi tubuh yang lebih kompleks dalam pola yang teratur dan dapat di ramalkan, sebagai hasil dari proses sebagai hasil dari proses pematangan. Disini menyangkut adanya proses diferensiasi dari sel-sel tubuh, jaringan tubuh, organ-organ dan sistem organ yang berkembang sedemikian rupa sehingga masing-masing dapat memenuhi fungsinya. Termasuk juga perkembangan emosi, intelektual dan tingkah laku sebagai hasil interaksi dengan lingkungannya. ${ }^{3}$

Menurut data dari Kementerian Kesehatan pada Tahun 2013 Presentase tertinggi pemberian ASI Eksklusif pada bayi usia $0-6$ bulan yaitu pada Provinsi Nusa Tenggara Barat sebesar $(79,75 \%)$ dan terendah pada Provinsi Maluku yaitu (25,2\%). Hasil analisis menunjukkan bahwa secara nasional, ASI eksklusif sebesar $(54,3 \%)$ dari jumlah total bayi usia 0-6 bulan dan bayiusia 0-6 bulan yang tidak diberikan ASI Eksklusif sebanyak 1.134 .952 bayi. ${ }^{4}$

Presentase pemberian ASI Eksklusif pada bayi usia $0-6$ bulan di Sulawesi Tengah pada tahun 2016 adalah $(56,3 \%)$ pada tahun 2017 mengalami peningkatan yaitu menjadi $(56,6 \%)$ dan pada tahun 2018 mengalami kenaikan yang tidak terlalu signifikan yaitu sebesar $(57,7 \%)^{5}$

Di seluruh dunia, angka kejadian sekitar 1\%-3\% anak-anak dibawah lima tahun dengan etiologi yang bervariasi. Berdasarkan sekitar 4 juta kelahiran/tahun di Amerika Serikat dan Kanada, antara 40.000 sampai 120.000 anak yang lahir setiap tahun di kedua negara ini akan terwujud keterlambatan perkembangan global. ${ }^{1}$

\section{METODOLOGI}

Penelitian menggunakan metode studi literature yang dimana mengumpulkan data pustaka, hasil penelitian - penelitian yang telah dilakukan dan berhubungan dengan topic penelitian ini serta membaca dan memahami dari isi tiap penelitian. Metode studi literature memanfaatkan sumber-sumber perpustakaan untuk memperoleh data penelitian, studi literature ini dilakukan untuk mengungkapkan teori - teori yang relevan sehingga bisa tercapainya landasan teori dan juga hasil penelitian, nantinya akan 
mengelompokkan hasil penelitian dari semua sumber di suatu tabel.

\section{HASIL DAN PEMBAHASAN}

\section{HASIL}

Berdasarkan hasil penelitian - penelitian yang dilakukan terdapat tiga interpretasi KPSP yaitu sesuai, meragukan, dan menyimpang. Hasil perkembangan bayi yang diberikan ASI Eksklusif sebagian besar menunjukkan interpretasi sesuai disusul interpretasi meragukan dan terakhir adalah interpretasi menyimpang dengan jumlah yang sedikit. Dari lima penelitian diatas dengan tiga interpretasi KPSP didapatkan tiga penelitian yang saling berhubungan dan bermakna secara signifikan, sedangakan terdapat dua penelitian dengan tiga interpretasi KPSP tidak menunjukkan adanya hubungan antara pemberian ASI Eksklusif dengan perkembangan bayi dan tidak bermakna.

Pada hasil penelitian dengan judul penelitian "Hubungan Pemberian Asi Eksklusif Terhadap Perkembangan Bayi Usia 6 Bulan di Desa Podosoko Kecamatan Sawangan Kabupaten Magelang Tahun 2013" menunjukkan bayi yang diberikan ASI eksklusif lebih dominan pada kategori sesuai dengan jumlah 29 bayi, sedangkan pada bayi yang tidak diberikan ASI Eksklusif menjukkan data lebih banyak pada kategori meragukan dengan jumlah 5 bayi.

Pada hasil penelitian dengan judul “ Tumbuh Kembang Bayi usia 6 Bulan yang Diberi ASI eksklusif dan Non Asi Eksklusif" didapatkan bayi yang telah ddiberikan ASI eksklusif kebanyakan terdapat pada kategori sesuai dengan jumlah 13 bayi dengan disusul kategori meragukan sebanyak 2 bayi, sedangkan bayi yang tidak diberikan ASI Eksklusif menunjukkan lebih banyak pada kategori meragukan dengan 12 bayi.

Untuk hasil penelitiaan "Pemberian ASI Eksklusif dengan Perkembangan Bayi Usia 6 Bulan di Wilayah Kerja Puskesmas Guntung Payung" menunjukkan bahwa pada bayi yang diberikan ASI eksklusif tersebut lebih banyak yang memuat kategori sesuai dengan jumlah 10 bayi dan pada bayi yang tidak diberikan ASI Eksklusif menunjukkan kategori sesuai dan meragukan dengan jumlah yang sama yaitu 8 bayi, sedangkan untuk menyimpangnya terdapat 1 bayi.

Pada penelitian "Perkembangan Bayi yang Diberikan ASI Eksklusif dan Non ASI Eksklusif di Wilayah Kerja Puskesmas Padang Karambia Payakumbuh Selatan" dari 19 bayi yang diberikan ASI Eksklusif menunjukkan 17 bayi yang kategori sesuai, 2 bayi yang kategori meragukan, dan tidak ada bayi yang perkembangannya menyimpang. Pada bayi yang tidak diberikan ASI Eksklusif terdapat 18 bayi yang memuat kategori perkembangan yang sesuai, 3 bayi yang memuat kategori perkembangan yang meragukan.

Pada Hasil penelitian "Hubungan Pemberian ASI eksklusif dengan Bayi Usia 0 6 di Kelurahan Sumbersari Bantul Metro Selatan Periode Februari-April Tahun 2017" menunjukkan bayi yang diberikan ASI Eksklusif lebih dominan pada kategori sesuai dengan jumlah 11 bayi dan 1 bayi memuat kategori meragukan . Pada bayi yang tidak diberikan ASI Eksklusif terdapat 8 bayi pada kategori sesuai, 6 bayi pada kategori meragukan, dan 4 bayi pada kategori menyimpang.

\section{PEMBAHASAN}

Pada salah satu penelitian berjudul "Hubungan Pemberian ASI Eksklusif Terhadap Tumbuh Kembang Bayi" menunjukkan lebih dominan kategori perkembangan yang sesuai pada bayi yang diberikan ASI eksklusif dengan jumlah 36 bayi, sedangkan pada penelitian "Hubungan Pemberian ASI Eksklusif Dengan Perkembangan Bayi Usia 3-6 Bulan di Wilayah Kerja Puskesmas Bangkinang Tahun 2018" menunjukkan data yang lebih banyak pada 26 bayi yang tidak diberikan ASI eksklusif dengan perkembangan yang menyimpang. Pada penelitian " Hubungan Pemberian Asi Eksklusif Terhadap Perkembangan Bayi Usia 6-9 Bulan di Desa Podosoko Kecamatan Sawangan Kabupaten Magelang Tahun 2013" menunjukkan jumlah bayi yang dominan pada bayi yang tidak diberikan ASI Eksklusif dengan kategori perkembangan yang meragukan dengan jumlah 25 bayi. Dari data diatas Penelitian ini menunjukkan bahwa terdapat hubungan 
antara pemberian ASI eksklusif dan perkembangan bayi usia 0-6 bulan.

Hasil ini sebanding dengan penelitian yang dilakukan oleh Pipiet Riani dkk di Kecamatan Darul Imarah Kabupaten Aceh Besar tahun 2014 bahwa ada hubungan signifikan antara pemberian ASI Eksklusif dengan perkembangan bayi. Selain itu, penelitian lain dari Ulfa Farrah lisa di Kelurahan Brontokusuman Kecamatan Mergangsan Yogyakarta tahun 2012 dan Aminatu Zuhriyah di wilayah kerja Puskesmas Cempaka Banjarbaru tahun 2012 juga menunjukan hasil yang sama yaitu terdapat hubungan antara ASI eksklusif dengan perkembangan bayi.

Secara garis besar tumbuh kembang anak dipengaruhi dua faktor yaitu faktor genetik dan lingkungan. Faktor lingkungan diantaranya adalah nutrisi atau gizi yang terdiri dari masa pre-natal dan pasca natal. Gizi memiliki peranan penting dalam tumbuh kembang anak, sehingga perlu untuk memberikan nutrisi yang terbaik. ASI merupakan makanan terbaik untuk bayi.ASI sangat dibutuhkan untuk kesehatan bayi dan mendukung pertumbuhan dan perkembangan bayi secara optimal. Bayi yang mendapatkan ASI eksklusif akan memperoleh semua kelebihan ASI serta terpenuhinya kebutuhan gizinya secara maksimal sehingga bayi lebih sehat, lebih tahan terhadap infeksi, tidak mudah terkena alergi, dan lebih jarang sakit karena ASI mengandung antibodi. Dengan demikian jika bayi yang mendapatkan ASI sacara eksklusif akan mengalami pertumbuhan yang optimal, hal ini dapat dilihat dari penambahan berat badan, panjang badan, atau lingkar kepala. ASI juga merpkanan makanan untuk perkembangan otak anak.ASI mengandung kolesterol tinggi yang diperlukan untuk mielinisasi. Demikian juga kadar AA dan DHA juga tinggi pada ASI. Anak yang mendapatkan ASI mempunyai kecerdasan yang lebih baik dari pada yang tidak mendapatkan ASI. 28

Ada beberapa mekanisme yangmembuat pemberian ASI bermanfaat bagi perkembangan anak. Pertama, ASI merupakan sumber asam lemak tak jenuh majemuk dengan rantai atom karbon yang panjang atau disebut long-chain polyunsaturated fatty acids (LCPUFA) yang bukan hanya merupakan sumber energi, tetapi juga merupakan molekulmolekul domain yang ditemukan dalam selubung myelin dan asam lemak tersebut sangat penting bagi perkembangan otak yang dapat mempengaruhi perkembangan motorik kasar dan halus, bahasa, serta sosial anak. ${ }^{6}$

Perkembangan bayi tidak hanya dipengaruhi oleh ASI namun juga dipengaruhi oleh banyak faktor lainya. Sebagaimana telah dijelaskan bahwa kebutuhan nutrisi bayi sampai usia 6 bulan akan terpenuhi oleh pemberian ASI Eksklusif saja, akan tetapi beberapa orang tua khawatir jika ASI yang diberikan tidak cukup untuk bayinya lantas menambahkan dengan produk-produk pendamping ASI atau bahkan pengganti AS . ${ }^{7}$

Pada bayi yang diberikan ASI Eksklusif terdapat bayi yang mengalami perkembangan yang meragukan dari fakta yang didapatkan pada saat penelitian bayi mempunyai keterlambatan pada aspek motorik kasar, sosialisasi dan kemandirian, hal ini terjadi akibat kurangnya stimulasi yang dilakukan oleh orang tua terhadap bayinya, karena proses pertumbuhan dan perkembangan tidak hanya berasal dari nutrisi saja tetapi stimulasi dan lingkungan yang mendukung juga dapat mempengaruhi perkembangan bayi. Perkembangan anak dipengaruhi oleh faktor genetik dan lingkungan, orang tua memegang peran untuk menciptakan lingkungan yang mendukung stimulasi yang diperlukan untuk perkembangan kognitif anak, dan juga menyediakan nutrisi yang adekuat. ${ }^{8}$

\section{SIMPULAN DAN SARAN}

Didapatkan Perkembangan bayi pada 10 penelitian yang telah dikumpulkan oleh peneliti menunjukkan bayi yang diberikan ASI Eksklusif ada 252 bayi yang memiliki perkembangan yang sesuai dan lebih banyak dibandingkan dengan bayi yang tidak diberikan ASI eksklusif Sedangkan untuk perkembangan pada bayi yang tidak diberikan ASI Eksklusif memiliki perkembangan yang menyimpang cukup banyak dengan jumlah 137 bayi. Sehingga dapat disimpulkan bahwa Pemberian ASI eksklusif dengan perkembangan bayi di Indonesia terdapat hubungan yang signifikan dan bermakna di 
Indonesia secara keseluruhan cakupan pemberian ASI Eksklusif masih sangat rendah.

\section{DAFTAR PUSTAKA}

1. WHO. The World Health Organization's infant feeding recommendation. 2019. Diakses tanggal 1 April 2019. https://www.who.int/elena/titles/exclusive breastfeeding/en/

2. Astutik., R.Y. 2014. Payudara dan Laktasi. Jakarta: Salemba Medika, pp. 12-3

3. Atiqa UD . 2016. Perbedaan Pertumbuhan dan Perkembangan Bayi Usia 6 Bulan yang Diberikan ASI Ekslusif dan Non Eksklusif di Wilayah Kerja Puskesmas Kelurahan Tamalanrea Makassar. Makassar.Universitas Hasanuddin

4. Pusat Data dan Informasi Kementerian Kesehatan. Situasi dan Analisis Asi Eksklusif. 2014.

5. Dinas Kesehatan Kota Palu. Hasil Pemantauan Cakupan ASI eksklusif Kota Palu Tahun 2018 .2019.

6. Rachmadani Z, Rusli R, Agustina R. Pemberian ASI Eksklusif dengan Perkembangan Bayi Usia 6 Bulan di Wilayah Kerja Puskesmas Guntung Payung . 2016

7. Sakinah N. Andayani NLN, Dinata IMK. Perbedaan Tingkat Perkembangan Bayi Yang Diberi Asi Esklusif Dan Non Eksklusif Di Wilayah Kerja Puskesmas Padang Karambi Kecamatan Payakumbuh Selatan. 2015

8. Sofiah D, Afiah I.Tumbuh Kembang Bayi Usia 6 Bulan yang Diberi ASI Eksklusif dan ASI non eksklusif . 2016 